\title{
OPINION
}

\section{A safe place for amphibians? A cautionary tale on the taxonomy and conservation of frogs, caecilians, and salamanders in the Brazilian Amazonia}

Is the Brazilian Amazonia a safe place for amphibians? Or is the occurrence of threatened species in the region greatly underestimated?

Talks on Amazonian biodiversity have become stagnated and predictable: "the Amazonia is a megadiverse biome and must be preserved before species become extinct... (large number of citations)". Although the statement is most certainly true, we should analyze it in more detail, taking into account our present taxonomic knowledge regarding extant amphibians. There are around 6638 described amphibian species in the World - 5858 anurans, 597 caudata, 183 caecilians (Frost 2010, last updated April 2010) - and these numbers are certainly already out of date as you are reading this. The rate of species description worldwide, especially in the tropics, is astonishing for most non-large mammal vertebrate groups (e.g. more than 200 new amphibian species were described in Zootaxa alone, from 2001 to October 2009; http://www.mapress.com/zootaxa/support/ Statistics.htm). Certainly, many more new taxa still await discovery and/or description. Sometimes the discovered species are not even cryptic! They are strikingly distinct and easily diagnosable; all we need is to find them, whether in the field or in old jars sitting in museum shelves, and then put some extra effort into understanding and describing this diversity.

Restricting the essay to the Brazilian Amazonia, AzevedoRamos \& GaLATTI (2002) mentioned a minimum of 163 amphibians with records in the region. They did, however, state that those numbers were underestimated, a fact confirmed later by Ávila-Pires et al. (2007) who mentioned 230 species (considering only entries up to March 2005). Discovery of new amphibian species in the region is not a rare fact (Heyer 2005, HeYer \& Crombie 2005, Peloso \& Sturaro 2008, Heinicke et al. 2009, Maciel et al. 2009, SIMÕES et al. 2010). Recently, even a new family of frogs was described from the Guiana in Venezuela, Brazil, and Guyana (Heinicke et al. 2009). For this, I am sure Azevedo-Ramos $\&$ Gallati (2002) were correct in assuming their position on the underestimation of amphibian diversity. I further add that the numbers from Ávila-Pires et al. (2007) are also likely an underestimation. But how is this relevant? Simple: effective conservation strategies, on a specific level, are difficult to plan if information is unavailable on how many species there are, and more important, what are the ranges, distributions and ecological needs of these species (AzEvEDo-RAMos \& GaLATTI 2002, DuboIs 2003, BRITO 2004). This is where taxonomy plays an important role (BRITo 2004) and where patience is a key factor, as correct species identification is critical in all stages of biological inventories.

Decision makers (politicians, "conservation biologists", and members of profit and non-profit conservation linked companies) usually pressure field biologists to compile detailed species lists in a short amount of time, commonly for poorly sampled areas. This pressure then is put on taxonomists for scientific names and classification of the collected taxa. Frequently, they need this information rather quickly. Taxonomy, however, is not a science that can be learned overnight and, in some cases, if not in most, a reliable identification to species level can only be achieved by an experienced specialist and may take a large amount of effort and time (Dubors 2003). The low number of specialists versus the high demand leads to less accurate identifications, which in turn can ignite a snowball effect. Non-specialist identifications, or even "hurried identification" by specialists, accumulate errors of many kinds over time (Dubois 2000, 2003).

Ultimately a misidentified specimen turns into incorrect information in online databases, which are heavily relied upon by end-users of such products. Sometimes, the endusers irresponsibly do not take the time to check and confirm the veracity of the data they are using. Museum database records are, among several other applications, commonly used in biodiversity assessment (KAISER 1999) and in modeling species distributions (e.g. Stockwell \& Peterson 2001, Fernandez et al. 2009), which, in turn, are used by "conservation biologists" to extrapolate distribution patterns and trends (Sсотт et al. 2002, Giovanelli et al. 2007). It is indeed of great importance that museum data is made public, but, at the same time, an extra amount of care should be taken when using museum online data to conduct evaluations, especially for species with limited data or for which taxonomy is complicated or unresolved (PAPES \& GAUBERT 2007). Furthermore, distribution models may be an important tool to predict species distributions but it is crucial that the next step is implemented, which is actually looking for the species where models predict their occurrence.

\footnotetext{
${ }^{1}$ The articles in the section OPINION are of sole responsibility of the authors and do not necessarily reflect the views of the editorial board.
} 


\section{Threatened amphibian species in the Brazilian Amazonia}

No amphibian from the Amazon biome was included in the official Brazilian list of species threatened with extinction (FundaÇão BIOdiversitas 2005). Numbers differ slightly from the Global Amphibian Assessment (GAA) list (Silvano \& Segalla 2005), where three Amazonian species with records in Brazil were included: Atelopus spumarius Cope, 1971, Hemiphractus johnsoni (Noble, 1917), and Oreophrynella quelchii Boulenger, 1895. This is a shockingly low number, considering the high diversity found in the region. However, let's have a closer look on these three species listed by (Silvano \& SEgalla 2005).

Atelopus spumarius - this species has a confusing taxonomic history. Several associated taxa were described along the Amazon basin (e.g. A. s. andinus Rivero, 1968 from southern Peru, A. barbotini Lescure, 1981 from French Guiana, and A. s. hoogmoedi Lescure, 1974 "1973" from the Guiana Shield). Some of those taxa were recognized as full species, subspecies or synonyms at some point in time (see NoONAN \& GAUCHER 2005 for details).

Recent consensus is that $A$. hoogmoedi should be treated as a full species (LÖTTERs et al. 2005, NOONAN \& GAUCHER 2005) and an implication of this is that there are actually two species of Atelopus Duméril \& Bibron, 1841 threatened with extinction in Brazil ( $A$. hoogmoedi and A. spumarius). I assume that if $A$. "spumarius" was correctly listed as threatened it seems logic to include both $A$. spumarius and $A$. hoogmoedi in the list because they each represent one fraction of the range of the broader A. "spumarius". However, for an unknown reason, these new taxonomic arrangements do not appear in recent (and up to date) compilations of species lists such as the AmphibiaWeb online database (АмрнівіаWев 2010) and the List of Amphibians from Brazil, published by the Brazilian Society of Herpetology (SBH 2010).

So are those species really threatened? Given the reasonably wide range of both species one would expect not. However, the range, in this case is misleading, since both species have apparently patchy distributions (Luger et al. 2008). The GAA assessors have listed A. spumarius as Vulnerable due to a "projected decline... inferred from declines on other high altitude Atelopus species... probably due to chytridiomycosis (my emphasis)" (Azevedo-Ramos et al. 2004). With the lack of actual evidence, this justification given by Azevedo-Ramos et al. (2004) is invalid. There is no evidence of chytridiomycosis (infection by Batrachochytrium dendrobatidis) in either A. spumarius or A. hoogmoedi (Azevedo-RAmos et al. 2004, Luger et al. 2008) and as reminded by AzEvEDo-RAmos et al. (2004), the species “...occurs below the altitude at which chytridiomycosis is normally a problem". Then, what is the reason to put it in the red list? The only other argument would then be habitat loss (A. spumarius was listed under criteria A3c; "population size reduction of $\geqslant 30 \%$, projected or suspected to be met within the next 10 years... based on a decline in area of occupancy, extent of occurrence and/or quality of habitat". This is highly speculative and many other species could be then included in this category based on the same arguments. Current evidence therefore points against placing $A$. spumarius and $A$. hoogmoedi in the red list, but evidence may be interpreted in different ways with a direct influence from the interpreters (Maloney 2007). A. hoogmoedi seems to be in a better situation than $A$. spumarius, since there is a greater amount of intact forests in the Guiana Shield, where the species is distributed, than in other parts of Amazonia (HUber \& Foster 2003).

The truth is that the unstable taxonomy of A. "spumarius" is an impediment for an accurate assessment of the species conservation status in Brazil. We need to urgently determine which of the known records refer to each species and only then extrapolate these data for secondary interpretations. Unfortunately, this may not be an easy task if we use conventional ways like checking the identification of museum records. Since both species look alike, a simple check of museum records might not be sufficient. Field work and an integrative taxonomy approach (e.g. genomics, bioacoustics) are needed.

Hemiphractus johnsoni (Noble, 1917) and Oreophrynella quelchii Boulenger, 1895 - the inclusion of these two species in the GAA threatened species lists is more easily justifiable than that of Atelopus. Both species have considerably limited distributions: $H$. johnsoni is known from just a few localities in western Amazonia (Sheil \& Mendelson 2001) and O. quelchii is restricted to the Mount Roraima Region and the record for Brazil is from Wei-Assipu-tepui on Guyana-Brazil border (SEÑARIS \& MaCCulloch 2005).

However, another important issue arises. Hemiphractus johnsohni actually has not been recorded in Brazil. Its presence in the country was based on a population from Parque Nacional da Serra do Divisor (PNSD) reported in a, then unpublished, PhD thesis (Souza 2003). This misled the GAA evaluators (CASTRO et al. 2004) to consider the species to occur in Brazil. Silvano \& Segalla (2005) listed $H$. johnsohni as one of three threatened species in the Brazilian Amazonia. At the time SouzA (2003) was unaware of the description of $H$. helioi Sheil \& Mendenson, 2001 from Ecuador and Peru two years prior to his work (SHEIL \& Mendelson 2001). However, Souza recently published the results of his PhD thesis in a book (Souza 2009) and corrected the identification of the Hemiphactus Wagler, 1828 population from PNSD to $H$. helioi. There are indeed no records of $H$. johnsoni to the state of Acre (M.Souza and P.S. Bernarde, pers. comm.). Thus, there are no confirmed records of $H$. johnsohni in Brazil. Here we have yet another example of misidentification with important conservation implications. H.helioi is listed as Least Concern in the GAA (ICocheA et al. 2004). The Global Amphibian Assessment threat status for many species is going through a revision (A. Angulo, pers. comm.), and hopefully this new information on Atelopus and Hemiphractus is updated.

\section{Non-frog amphibians}

If reliable information is critical for frogs, what to say about Caudata (salamanders) and Gymnophiona (caecilias)? Even with the increasing number of publications of amphibian systematics in Brazil, salamanders and to a lesser degree 
caecilians have been neglected. I will therefore briefly comment on the current status and trends in taxonomy and conservation implications for both groups.

\section{Caudata}

Officially only one species of salamander is recognized to occur in Brazil, Bolitoglossa paraensis (Unterstein, 1930), but unfortunately the group has not received the attention it deserves by Brazilian researchers. Ávila-PIREs et al. (2007) mentioned a second, undescribed, species from western Amazonia.

The taxonomy of Brazilian Bolitoglossa Bibron \& Duméril, 1854 was briefly assessed by Miranda-Ribeiro (1937), Brame \& WAKE (1963) and Parra-Olea et al. (2004). The later taxonomic action was the revalidation of Bolitoglossa paraensis for the species occurring in Brazil (Parra-Olea et al. 2004). However it is worth noting that, based solely on molecular data, Parra-Olea et al. (2004) stated that B. paraensis, as recognized by them, "should be considered a species complex in need of a detailed study". In fact they erected the name based on specimens from western Amazonia (Acre and Amazonas), but the type-locality of $B$. paraensis is Santa Isabel do Pará, a locality further east (over 1000 $\mathrm{km}$ ) from the samples analyzed by Parra-Olea et al. (2204). Based on their own findings ("large divergence found among the three sequences") applying the name $B$. paraensis for the populations treated by PARRA-OlEA et al. (2004) was incorrect. In fact, the whole taxonomy of Brazilian Bolitoglossa needs to be reevaluated (a revisionary study of Brazilian Bolitoglossa is currently underway, S. Neckel-Oliveira, pers. comm.).

Again, taxonomic instability made the GAA (2004) list Bolitoglossa altamazonica (Cope, 1874) as the species occurring in Brazil and neglect the occurrence of B. paraensis in the country. Although B. paraensis was included in the list of threatened species of Pará (as vulnerable), it is unlikely that the species is declining for any reason other than habitat destruction. Bolitoglossa specimen have been found in several sites along the region of Belém (EstupiÑán 2007: fig. 3) and more recently in the state of Amapá as well as in the municipalities of Bragança, Ourem, Juruti and Itaituba in the state of Pará (specimens from Juruti may represent a new undescribed species, M.S. Hoogmoed, pers. comm.), indicating a possible wider distribution of the genus in the state. Whether all those records represent a single widespread species remains to be adequately verified. It seems the species can tolerate a certain degree of habitat disturbance (CRUMP 1997, EstupiÑán 2007), which suggests a positive future.

\section{Gymnophiona}

Secretive habits (they usually live in the water or buried in the ground or in rotten trees) of caecilians make them difficult to find and collect, demanding a special and directional sampling effort. The Gymnophiona is, for that matter, probably one of the most poorly known groups of amphibians (GOWER \& WILKINSON 2005). Data on distribution and ecology is lacking for most species and the relative rarity of specimens in collections has considerably held back advances in basic taxo- nomic knowledge of these intriguing animals (Gower \& Wilkinson 2005, Maciel et al. 2009). According to Maciel et al. (2009), few contributions to the taxonomy of Neotropical Gymnophiona have been made since the monographic work by TAYLOR (1968), and the discovery of new species has been sporadic. On the upside, a revisionary work on the Gymnophiona of the Brazilian Amazonia was just finished by A.O. Maciel and M.S. Hoogmoed (MPEG) as the master thesis of the former under the advice of the latter. An initial result from their work was the recent description of a second species of the previously monotypic genus Brasilotyphlus Taylor, 1968 (MACIEL et al. 2009). Publication of Maciel and Hoogmoed's results hopefully stimulates further research projects on Gymnophiona. Their data might also be used by redlist evaluators for the reevaluation of the conservation status of some species.

\section{Threats}

Many factors have been reported as threats to the survival of amphibian species. Habitat loss and fragmentation are certainly the main factors threatening biodiversity worldwide and this is no different for Brazilian amphibians (Young et al. 2001, Silvano \& Segalla 2005, Becker et al. 2007). Forest logging, mining, agriculture, dam building, artificial lakes, roads, industrial development, and tourism development are just a few examples of how frog habitats might be destroyed or at least highly compromised. Other than habitat loss and fragmentation, factors such as introduction of alien species (KaTs \& FerRer 2003), climate shifts (Pounds et al. 2006, Lips et al. 2008), agrochemicals contamination (Relyea 2005, Pounds et al. 2006) and diseases (LiPs et al. 2008) also seem to be important threats to the health of amphibian populations. Perhaps the most important disease affecting amphibian populations worldwide is the chytridiomycosis caused by the fungus Batrachochytrium dendrobatidis Longcore, Pessier \& Nichols, 1999 (Bd). The fungus reportedly increases mortality rates in some infected populations (BERGER et al. 1998) ultimately leading to mass population declines and extinctions (Mendelson et al. 2005, La Marca et al. 2005). Although reports of $B d$ existed for South America (Ron \& Merino-ViterI 2000, Silvano \& SEgalla (2005) mentioned that no cases of infection by $B d$ were known for Brazil at the time of their report. However, since their report, several cases of infection by $B d$ were reported in the Atlantic Rainforest (CARnaval et al. 2006, Toledo et al. 2006). The fungus has not yet been reported from the Brazilian Amazonia, but a thorough search for it has also not been done. Note, however, that the major portion of the Brazilian Amazonia is below the altitudes at which $B d$ become dangerous (MCDONALd \& Alford 1999). Atelopus species are apparently highly susceptible to Bb infection (LA Marca et al. 2005, Lips et al. 2008) especially at mid to high elevations. Monitoring the status of the Atelopus populations from the Brazilian Amazonia is necessary (LUGER et al. 2008). Unfortunately, no monitoring at all is being done on the species in the Brazilian territory... yet another lost opportunity. 


\section{Least concern does not necessarily mean no concern ${ }^{2}$}

Two of the "threat level categories" in the GAA and other threatened species lists are Data Deficient (DD) and the Least Concern (LC). The DD species are literally species for which data is unavailable for rigorous assessments of their status. According to IUCN (2001) a "taxon is Least Concern when it has been evaluated against the criteria and does not qualify for Critically Endangered, Endangered, Vulnerable or Near Threatened. Widespread and abundant taxa are included in this category" (my emphasis). A complete discussion of all Least Concern species would be too extensive and beyond the objective of this essay, so the cautionary advice here is not to treat widespread and abundant taxa as Least Concern without a detailed examination of their taxonomy and ecological needs. Allobates brunneus (Cope, 1887) is a good example. The species was once thought to be widespread but taxonomic reevaluations showed it to represent a complex of species (Silvano et al. 2004). Populations from Venezuela have been recognized as distinct species (LA MARCA et al. 2004a) while Morales (2000) restricted the distribution of the species to lowlands south of the Amazon river in the basins of the Madeira, Tapajós and Xingu rivers. Lima et al. (2009) redescribed A. brunneus from the vicinities of the type locality and briefly mentioned that the species has not been found in several sites near the type locality in Chapada dos Guimarães. Given existing reports of declines in populations of Allobates in other regions of Brazil (IZECKSOHN \& CARVALHO-E-SILVA 2001, GaSPARINI et al. 2007) we should at least turn on the yellow light for the conservation status of $A$. brunneus.

What about the Leptodactylus of the marmoratus group? Two species are considered widespread in the Amazon ( $L$. andreae Müller, 1923 and L. hylaedactylus (Cope, 1868) but it is widely known that both represent complexes of species (ANGULO \& Reichle 2008, A. Angulo pers. comm. in La Marca et al 2004b, c). Are all known, but undescribed, species in the complexes also of Least Concern? Are those really widespread entities? In this case, the poor taxonomic knowledge prevent us from adequately answering that question. The bad news is that it may take a while for the taxonomy of L. andreae and L. hylaedactylus complexes to get at least fairly understood.

\section{What could and what should be done}

I see two steps towards a better comprehension of herpetofauna diversity in Amazonia and ultimately the elaboration of efficient conservation plans for threatened and rare species.

The first step is to study geographic and population variation within postulated species in a denser degree, and also incorporate additional techniques for species delimitation and consequent recognition. In the specific case of amphibians, refined morphological, bioacoustic and molecular studies have increased accuracy of prediction of species limits but these tools (especially bioacoustics and genomics) are still underused and should be incorporated in a much greater scale in taxonomic studies in the Amazon. Many "widespread" taxa have proven to be species complexes through the use of "integrative taxonomy" - examples in Allobates (Lima \& Caldwell 2001, Lima et al. 2009, Simões et al. 2010), Atelopus (Noonan \& Gaucher 2005), Leptodactylus of the marmoratus group (ANGUlo et al. 2003, ANGUlo \& Reichle 2008), and Pristimantis fenestratus (Padial \& De la Riva 2009). Morphology alone has also proven to still be an effective tool for recognition of amphibian diversity in Amazonian Chiasmocleis (Peloso \& STURARo 2008, pers. obs.), Leptodactylus of the pentadactylus group (HEYer 2005).

The second step is to send well trained herpetologists to the field to collect specimens and associated data (tissue samples, behavior, reproductive data, and advertisement call), especially in subsampled or unsampled areas. Then get those collected specimens and data in the hands of trained herpetology taxonomists.

To achieve those goals, a great deal of investment is needed, both in biodiversity inventories, and in the continued formation of taxonomists and field biologists. Fortunately for Brazil, we are one of the leading countries in the science of taxonomy/systematics (Carvalho et al. 2008, Michán L. \& J. LLORENTE-BOUSQUETS 2010).

Other good news is that initiatives for development of such basic sciences such as taxonomy and biodiversity research in Brazilian Amazonia received some attention during the last decade. One fair example is the Programa de Pesquisa em Biodiversidade (PPBio), created in 2004 by the Brazilian Ministry of Science and Technology. With the two major scientific institutions of Brazilian Amazonia [Museu Paraense Emílio Goeldi (MPEG), in Belém, Pará and Instituto Nacional de Pesquisas da Amazonia (INPA), in Manaus, Amazonas] directly involved, the PPBio funds provided critical infrastructure modernization for participating institutions, structured and long term biodiversity inventories, and fellowships for students and technicians at all levels, both in ecology and in systematic works. Regarding exclusively amphibians, published products of such initiatives include inventories of the frogs from Reserva Adolpho Ducke, Amazonas (Lima et al. 2006) and a new species of narrow mouthed frog discovered in Caxiuanã (Peloso \& Sturaro 2008). Several master and doctoral thesis have been developed with PPBio research funds and within PPBio research sites. Further contributions can be expected in the near future as the program contin-

\footnotetext{
${ }^{2}$ After this paper was accepted for publication I had access to a publication by ANGULo \& ICOCHEA (2010) where they describe a new species of the Leptodactylus marmoratus group and provide a lengthy discussion on the conservation implication for species complexes. Although put in a slightly different way, I generally agree with the ideas by Angulo and Icochea and encourage reading of the paper for a detailed practical example of what I breafly treat in this section.
}

ZOOLOGIA 27 (5): 667-673, October, 2010 
ues and expands. Hopefully more initiatives similar to PPBio will be implemented and those already existing will be perpetuated.

Answering the main question, of whether the Brazilian Amazonia is a safe place for amphibians, the very truth is that we do not know. We cannot access the true status of conservation of the amphibian biota in Amazonia with our current taxonomic and biogeographic knowledge for this mysterious, yet fascinating, region.

\section{ACKNOWLEDGEMENTS}

A. Maciel, C.F.B. Haddad, J.C. Costa, M. Sturaro, Swati Patel, and two anonymous reviewers provided comments, suggestions, criticism, and encouragement to publish these ideas. I acknowledge that reviewers do not agree with all ideas presented here, and what is published is my sole responsibility. I thank Coordenação de Aperfeiçoamento de Pessoal de Nível Superior/Fulbrigth Comission/American Museum of Natural History (CAPES/Fulbright/AMNH, process BEX 2806/09-6) for a graduate fellowship. Part of this work was done while a research associate in the Laboratório de Herpetologia, Museu Paraense Emílio Goeldi, Belém, Brazil. I thank T.C.S. Avila-Pires and A.L.C. Prudente for providing me with working space there.

\section{LITERATURE CITED}

АмрнівіаWев. 2010. Information on amphibian biology and conservation. AmphibiaWeb, Berkeley, California. Available online at: http://amphibiaweb.org. [Accessed: 14.X.2010].

Angulo, A. \& S. Reichle. 2008. Acoustic signals, species diagnosis, and species concepts: the case of a new cryptic species of Leptodactylus (Amphibia: Anura: Leptodactylidae) from the Chapare region, Bolivia. Zoological Journal of the Linnean Society 152: 59-77.

Angulo, A. \& J. Icochea. 2010. Cryptic species complexes, widespread species and conservation: lessons from Amazonian frogs of the Leptodactylus marmoratus group (Anura: Leptodactylidae). Systematics and Biodiversity 8: 357-370.

Ávila-Pires, T.C.S.; M.S. Hoogmoed \& L.J. VitT. 2007. Herpetofauna da Amazônia, p. 13-43. In: L.B. Nascimento \& M. E. Oliveira (Orgs). Herpetologia do Brasil II. Belo horizonte, Sociedade Brasileira de Herpetologia, 354p.

Azevedo-Ramos, C. \& U. Galatti. 2002. Patterns of Amphibian Diversity in Brazilian Amazonia: Conservation Implications. Biological Conservation 103: 103-111.

Azevedo-Ramos, C.; S. Ron; L.A. Coloma; M.R. Bustamante; A. Salas; R. Schulte; S. Lötters; A. Angulo; F. CAstro; J. Lescure; C. Marty; E. La Marca \& M. Hoogmoed. 2004. Atelopus spumarius. In: IUCN (Ed.). Red List of Threatened Species. Version 2010.1. International Union for Conservation of Nature, available online at http://www.iucnredlist.org [Assessed: 31.V.2010].

Becker, C.G.; C.R. Fonseca, C.F.B. Haddad, R.F. Batista \& P.I. PraDo. 2007. Habitat split and the global decline of amphibians. Science 318: 1775-1777.
Berger, L.; R. Speare; P. Daszak; D.E. Green; A.A. Cunningham; C.L. Goggin; R. Slocombe; M.A. Ragan; A.D. Hyatt; K.R. McDonald; H.B. Hines; K.R. Lips; G. Marantelli \& H. Parkes. 1998. Chytridiomycosis causes amphibian mortality associated with population declines in the rain forests of Australia and Central America. Proceedings of the National Academy of Science 95: 9031-9036.

Brame-Jr, A.H. \& D.B. WaKe. 1963. The salamanders of South America. Contributions in Science, Natural History Museum of Los Angeles County 69: 1-72.

BRITo, D. 2004. Lack of adequate taxonomic knowledge may hinder endemic mammal conservation in the Brazilian Atlantic Forest. Biodiversity and Conservation 13: 2135-2144.

Carnaval A.C.; R. Puschendorf; O.L; Peixoto; V.K. Verdade \& M.T. RODRIGUES. 2006. Amphibian chytrid fungus broadly distributed in the Brazilian Atlantic Rain Forest. Ecohealth 3: 41-48.

Carvalho, M.R.; F.A. Bockmann; D.S. Amorim; C.R.F. Brandão, M. De Vivo; J.L. De Figueiredo; H.A. Britski; M.C.C. De Pinna; N.A. Menezes; F.P.L. Marques; N. Papavero; E.M. Cancello; J.V. Crisci; J.D. McEachran; R.C. Schelly; J.G. Lundberg; A.C. Gill; R. Britz; Q.D. Wheeler; M.L.J. Stiassny; L.R. Parenti; L.M. Page; W.C. Wheeler; J. Faivovich; R.P. Vari; L. Grande; C.J. Humphries; R. DeSalle; M.C. Ebach \& G.J. Nelson. 2007. Taxonomic Impediment or Impediment to Taxonomy? A Commentary on Systematics and the Cybertaxonomic-Automation Paradigm. Evolutionary Biology 34: 140-143.

Castro, F.; J. Lynch \& C. Gascon. 2004. Hemiphractus johnsoni. In: IUCN (Ed.). Red List of Threatened Species. Version 2010.1. International Union for Conservation of Nature, available online at http://www.iucnredlist.org [Assessed: 31.V.2010].

CRUMP, M. 1977. Intrapopulation and interspecific variation of standard morphological characters of four closely related South American salamanders (Bolitoglossa), with description of habitat preferences. Herpetologica 33: 415-426.

Duвois, A. 2000. Synonymies and related lists in zoology: general proposals, with examples in herpetology. Dumerilia 4: 33-98.

Dubors, A. 2003. The relationships between taxonomy and conservation biology in the century of extinctions. Comptes Rendus Biologies 326: S9-S21.

Elmer, K.R. \& D.C. Cannatella. 2008 Three new species of leaflitter frogs from the upper Amazon forests: cryptic diversity within Pristimantis "ockendeni" (Anura: Strabomantidae) in Ecuador. Zootaxa 1784: 11-38.

EstupIÑ̃́n, R.A. 2007. Recentes registros de Bolitoglossa paraensis (Unterstein, 1930) (Caudata, Plethodontidae) no centro de endemismo Belém. Uakari 3: 91-95.

Fernández, M.; D. Cole; W.R. Heyer, S. Reichle \& R.O. de Sá. 2009. Predicting Leptodactylus (Amphibia, Anura, Leptodactylidae) distributions: broad-ranging versus patchily distributed species using a presence-only environmental niche modeling technique. South American Journal of Herpetology 4: 103116. 
Frost, D.R. 2010. Amphibian Species of the World: an Online Reference. Version 5.4. New York, American Museum of Natural History, available online at http://research.amnh.org/ herpetology/amphibia [Accessed: 31.V.2010].

FundaÇão BIOdiversitas. 2005. Lista da fauna brasileira ameaçada de extinção: incluindo as espécies quase ameaçadas e deficientes em dados. Belo Horizonte, Fundação Biodiversitas, 160p.

Gasparini, J.L.; A.P. Almeida; C.A.G. Cruz \& R.N. Feio. 2007. Anfíbios, p. 75-86. In: M. Passamani \& S.L. Mendes (Orgs). Livro de Espécies Ameaçadas de Extinção no Espírito Santo. Vitória, IPEMA, Gráfica GSA, 140p.

Giovanelli, J.G.R.; C.F.B. Haddad \& J. Alexandrino. 2008. Predicting the potential distribution of the alien invasive American bullfrog (Lithobates catesbeianus) in Brazil. Biological Invasions 10: 585-590.

Gower, D.J. \& M.Wilkinson. 2005. Conservation Biology of caecilian amphibians. Conservation Biology 19: 45-55.

Heinicke, M.P.; W.E. Duellman; L. Trueb; D.B. Means; R.D. MacCulloch \& S.B. Hedges. 2009. A new frog family (Anura: Terrarana) from South America and an expanded direct-developing clade revealed by molecular phylogeny. Zootaxa 2211: 1-35.

Heyer W.R. \& R.I. Crombie. 2005. Leptodactylus lauramiriamae, a distinctive new species of frog (Amphibia: Anura: Leptodactylidae) from Rondônia, Brazil. Proceedings of the Biological Society of Washington 118: 590-595.

HeYeR, W.R. 2005. Variation and taxonomic clarification of the large species of the Leptodactylus pentadactylus species group (Amphibia: Leptodactylidae) from Middle America, northern South America, and Amazonia. Arquivos de Zoologia 37: 269-348.

Huber, O. \& M.N. Foster. 2003. Conservation Priorities for the Guayana Shield. Washington, D.C., Conservation International, 99p.

ICOChea, J.; L.A. Coloma; S. Ron; K. Jungfer; F. CASTro \& J.V. Rueda. 2004. Hemiphractus helioi. In: IUCN (Ed.). Red List of Threatened Species. Version 2010.1. International Union for Conservation of Nature, available online at http:// www.iucnredlist.org [Assessed: 31.V.2010].

IUCN. 2001. IUCN Red List Categories and Criteria: Version 3.1. Cambridge, International Union for Conservation of Nature Species Survival Commission, 49p.

Izecksohn, E. \& S.P Carvalho-e-Silva. 2001. Anfíbios do Município do Rio de Janeiro. Rio de Janeiro, Editora da UFRJ, 147p.

KaISER, J. 1999. Searching museums from your desktop. Science 284: 888.

Kats, L.B. \& R.P. Ferrer. 2003. Alien predators and amphibian declines: review of two decades of science and the transition to conservation. Diversity and Distributions 9: 99-110.

La Marca, E.; K.R. Lips; S. Lötters; R. Puschendorf; R. Ibáñez; J.V. Rueda-Almonacid; R. Schulte; C. Marty; F. Castro; J. Manzanilla-Puppo; J.E. García-Pérez; F. Bolaños; G. Chaves; J.A. Pounds; E. Toral \& B.E. Young. 2005. Catastrophic population declines and extinction in neotropical harlequin frog
(Bufonidae: Atelopus). Biotropica 37: 190-201

la Marca, E.; J. Manzanilla \& A. Mijares-Urrutia. 2004a. Revisión taxonómica del Colostethus del norte de Venezuela confundido durante largo tiempo con C. brunneus. Herpetotropicos 1: $40-50$.

La Marca, E.; C. Azevedo-Ramos; L.A. Coloma \& S. Ron. 2004b. Leptodactylus andreae. In: IUCN (Ed.). Red List of Threatened Species. Version 2010.1. International Union for Conservation of Nature, available online at http://www.iucnredlist. org [Assessed: 31.V.2010].

La Marca, E.; L.A. Coloma; S. Ron; C. Azevedo-Ramos; D. Silvano \& J. HARDy. 2004c. Leptodactylus hylaedactylus. In: IUCN (Ed.). Red List of Threatened Species. Version 2010.1. International Union for Conservation of Nature, available online at http://www.iucnredlist.org [Assessed: 31.V.2010].

Lima, A.P. \& J.P. Caldwell. 2001. A new amazonian species of Colostethus with sky blue digits. Herpetologica 57: 180-189.

Lima, A.P.; W.E. Magnusson; M. Menin; L.K. Erdtmann; D.J. Rodrigues; C. Keller \& W. Hödl. 2006. Guide to the frogs to Reserva Adolpho Ducke, central Amazonia. Manaus, Áttema Design Editorial, 168p.

Lima, A.P.; J.P. Caldwell \& C. Strussmann. 2009. Redescription of Allobates brunneus (Cope 1887) (Anura: Aromobatidae: Allobatinae), with a description of the tadpole, call, and reproductive behavior. Zootaxa 1988: 1-16.

Lips, K.; R.J. Diffendorfer; J.R. Mendelson III \& M.W. Sears. 2008. Riding the wave: Reconciling the roles of disease and climate change in amphibian declines. PLoS Biology 6: 441-454.

LÖTTERS, S. \& I. DE LA Riva. 1998. Redescription of Atelopus tricolor Boulenger from southeastern Peru and adjacent Bolivia, with comments on related forms. Journal of Herpetology 32: 481-488.

Lötters, S.; R. Boistel; M. Blanc; C.F.B. Haddad \& A. van der Meijden. 2005. Atelopus hoogmoedi, p. 132-134. In: J.V. RUEDA-ALMONACID; J.V. Rodríguez-Mahecha; S. Lötters; E. La Marca;T. Kahn \& A. Angulo (Eds). Ranas arlequines. Bogotá, Conservación Internacional, Panamericana Formas e Impresos, 202p.

Luger, M.; T.W.J. Garner; R. ERnst; W. HöDl \& S. LÖtters. 2008. No evidence for precipitous declines of harlequin frogs (Atelopus) in the Guyanas. Studies on neotropical fauna and environment 43: 177-180.

Maciel, A.O.; T. Mott \& M.S. Hoogmoed. 2009. A second Brasilotyphlus (Amphibia: Gymnophiona: Caeciliidae) from Brazilian Amazonia. Zootaxa 2226: 19-27.

Maloney, J. 2007. Children's roles and use of evidence in science: an analysis of decision-making in small groups. British Educational Research Journal 33: 371-401.

Mendelson J.R.; E.D. Brodie-Jr; J.H. Malone; M.E. Acevedo; M.A. Baker; M.J. Smatresk \& J.A. Campbell. 2005. Factors associated with the catastrophic decline of a cloudforest frog fauna in Guatemala. Revista de Biologia Tropical 52: 991-1000

McDonald, K. \& R. Alford. 1999. A review of declining frogs in northern Queensland, p. 14-22. In: A. CAMPBELL (Ed.). Declines 
and Disappearances of Australian Frogs. Canberra, Environment Australia, 236p.

Michán L. \& J. Llorente-Bousquets. 2010. Bibliometria de la sistematica biologica sobre America Latina durante el siglo XX en tres bases de datos mundiales. Revista de Biología Tropical/International Journal of Tropical Biology and Conservation 58: 531-554.

Miranda-Ribeiro, A. 1937. Alguns batráquios novos das colecções do Museu Nacional. O Campo 1937: 66-69.

Morales, V.R. 2000 [2002]. Sistemática y biogeografia del grupo trilineatus (Amphibia, Anura, Dendrobatidae, Colostethus), con descripcion de once nuevas especies. Publicaciones de la Asociacion Amigos de Donana 13: 1-59.

NOONAN, B.P. \& P. GAUCHER. 2005. Phylogeography and demography of Guianan harlequin toads (Atelopus): Diversification within a refuge. Molecular Ecology 14: 3017-3031.

PAdial, J.M. \& I. De la Riva. 2009. Integrative taxonomy reveals cryptic Amazonian species of Pristimantis (Anura). Zoological Journal of the Linnaean Society 155: 97-122.

Papes, M. \& P. Gaubert. 2007. Modelling ecological niches from low numbers of occurrences: assessment of the conservation status of poorly known viverrids (Mammalia, Carnivora) across two continents. Diversity and Distributions 13: 890-902.

Parra-Olea, G.; M. García-París \& D.B. Wake. 2004. Molecular diversification of salamanders of the tropical American genus Bolitoglossa (Caudata: Plethodontidae) and its evolutionary and biogeographical implications. Biological Journal of Linnean Society 81: 325-346.

Peloso, P.L.V. \& M.J. Sturaro. 2008. A new species of narrowmouthed frog of the genus Chiasmocleis Méhelÿ 1904 (Anura, Microhylidae) from the Amazonian rainforest of Brazil. Zootaxa 1947: 39-52.

Pounds, J.A.; M.R. Bustamante; L.A. Coloma; J.A. Consuegra; M.P.L. Fogden; P.N. Foster; E. La Marca; K.L. Masters; A. Merino-Viteri; R. Puschendorf; S. Ron; G.A. SÁnchez-Azofeifa; C.J. Still \& B.E. Young. 2006. Widespread amphibian extinctions from epidemic disease driven by global warming. Nature 39: 161-167.

ReLyeA, R.A. 2005. The lethal impact of Roundup on aquatic and terrestrial amphibians. Ecological Applications 15: 1118-1124

Ron S. \& A. Merino-Viteri. 2000. Amphibian declines in Ecuador: overview and first report of chytridiomycosis from South America. Froglog 42: 2-3.

SBH. 2010. Brazilian amphibians - List of species. Curitiba, Sociedade Brasileira de Herpetologia, available online at http://www.sbherpetologia.org.br [Accessed: 14.X.2010].
Scott, J.M.; P.J. Heglund \& M.L. Morrison. 2002. Predicting species occurrences: Issues of scale and accuracy. Washington, D.C., Island Press, 868p.

Señaris, J.C. \& R.D. MacCulloch. 2005. Amphibians. Bulletin of the Biological Society of Washington 13: 8-23.

Sheil, C.A. \& J.R. Mendelson. 2001. A new species of Hemiphractus (Anura: Hylidae: Hemiphractinae), and a redescription of H. johnsoni. Herpetologica 57: 189-202.

Simões, P.I.; A.P. LIMA \& I.P. Farias. 2010. The description of a cryptic species related to the pan-Amazonian frog Allobates femoralis(Boulenger 1883) (Anura: Aromobatidae). Zootaxa 2406: 1-28

Silvano, D.; E. La Marca \& S. Reichle. 2004. Allobates brunneus. In: IUCN (Ed.). Red List of Threatened Species. Version 2010.1. International Union for Conservation of Nature, available online at http://www.iucnredlist.org [Assessed: 31.V.2010].

Silvano, D.L. \& M.V. Segalla. 2005. Conservation of Brazilian Amphibians. Conservation Biology 19: 653-658.

SouzA, M. B. 2003. Diversidade de anfíbios nas unidades de conservação ambiental: Reserva Extrativista do Alto Juruá (REAJ) e Parque Nacional da Serra do Divisor (PNSD), Acre, Brasil. Rio Claro, PhD Thesis, Universidade Estadual Paulista.

SouzA, M.B. 2009. Anfíbios: Reserva Extrativista do Alto Juruá e Parque Nacional da Serra do Divisor, Acre. Campinas, Editora do Instituto de Filosofia e Ciências Humanas, 77p.

Stockwell, D.R.B. \& A.T. Peterson. 2002. Effects of sample size on accuracy of species distribution. Models Ecological Modelling 148: 1-13.

TAYLOR, E.H. 1968. The Caecilians of the World: A taxonomic review. Lawrence, University of Kansas Press, 848p.

Toledo L.F.; C.F.B. Haddad; A.C.O.Q. Carnaval \& F.B. BritTo. 2006. A Brazilian anuran (Hylodes magalhaesi: Leptodactylidae) infected by Batrachochytrium dendrobatidis: a conservation concern. Amphibian and Reptile Conservation 4: 17-21.

Young, B.E.; K.R. Lips; J.K. Reaser; R. IbáÑez; A.W. Salas; J.R. Cedeño; L.A. Coloma; S. Ron; E. La Marca; J.R. Meyer; A. Muñoz; F. Bolaños; G. Chaves \& D. Romo. 2001. Population declines and priorities for Amphibian conservation in Latin America. Conservation Biology 15: 1213-1223.

Submitted: 08.V.2010; Accepted: 30.VI.2010.

Editorial responsibility: Heraldo L. de Vasconcelos

\section{Pedro Luiz Vieira Peloso}

Richard Gilder Graduate School and Division of Vertebrate Zoology (Herpetology), American Museum of Natural History. Central Park West at 79th Street, 10024, New York, NY, USA. E-mail: ppeloso@amnh.org; pedropeloso@gmail.com 